\title{
EVALUATION OF PHYSIOLOGICAL RESPONSES OF CALVES DURING RAINY SEASON IN THE SEMIARID ENVIRONMENT
}

\author{
[Avaliação das respostas fisiológicas de bezerros durante a estação chuvosa em ambiente semiárido]
}

\begin{abstract}
Maiko Roberto Tavares Dantas ${ }^{1}$, João Batista Freire de Souza Jr ${ }^{1 *}$, Renata Nayhara de Lima ${ }^{1}$, Jânio Lopes Torquato², Geovan Figueirêdo de Sá Filho ${ }^{2}$, Herica Girlane Tertulino Domingos ${ }^{1}$, João Paulo Araújo Fernandes de Queiroz ${ }^{1}$, Patrícia de Oliveira Lima ${ }^{3}$, Leonardo Lelis de Macedo Costa ${ }^{3}$
\end{abstract}

${ }^{1}$ Programa de Pós-Graduação em Ciência Animal, Universidade Federal Rural do Semi-Árido, Mossoró, RN.

${ }^{2}$ Programa de Pós-Graduação em Ecologia e Conservação, Universidade Federal Rural do Semi-Árido, Mossoró, RN.

${ }^{3}$ Professor do Departamento de Ciências Animais, Universidade Federal Rural do Semi-Árido, Mossoró, RN.

\begin{abstract}
The aim of this study was to evaluate the physiological responses of calves during rainy season. The respiratory rate $\left(R_{R}\right)$, rectal temperature $\left(R_{T}\right)$, and surface temperature $\left(T_{S}\right)$ of 23 calves were measured during the period from 7:00 to 18:00 h. Air temperature $\left(T_{A}\right)$, relative humidity $\left(R_{H}\right)$, wind speed $(U)$ and mean radiant temperature $\left(M_{R T}\right)$ were also measured. With a portable thermographic camera, thermal images were obtained and four body regions were chosen (face, neck, body and legs). The analysis of variance (ANOVA) revealed a significant effect of day period on the $R_{T}$ and $T_{S}$, but not for the $R_{R}$. The ANOVA also found a significant effect of body region on the $T_{S}$, where the thermographic analysis revealed that the facial region showed higher temperature than other body regions. Thus, it is concluded that the calves maintained their body temperature at normal levels throughout all day without the need for activation of heat loss by respiratory evaporation, which shows a situation of thermal comfort. There are regional differences in the $T_{S}$, where the body regions that have higher temperatures are responsible for most of the high sensible heat loss, as the face.
\end{abstract}

Keywords: respiratory rate; ruminants; rectal temperature; surface temperature; thermal images.

RESUMO - Objetivou-se com este estudo avaliar as respostas fisiológicas de bezerros durante a estação chuvosa. A frequência respiratória (FR), temperatura retal (TR) e temperatura da superfície corporal (TS) de 23 bezerros foram mensuradas durante o período de 07:00 às 18:00 horas. Também foram coletadas a temperatura do ar (TA), umidade relativa (UR), velocidade do vento (U) e temperatura radiante média (TRM). Com uma câmera termográfica portátil, imagens térmicas foram obtidas e quatro regiões do corpo foram escolhidas (face, pescoço, corpo e patas). A análise de variância (ANOVA) revelou um efeito significativo do horário sobre a TR e TS, mas não para o FR. A ANOVA também encontrou um efeito significativo da região corporal sobre a TS, onde a análise mostrou que a região facial apresentou temperatura mais elevada do que outras regiões do corpo. Assim, conclui-se que, mesmo apresentando pequenas variações, os bezerros mantiveram a sua temperatura corporal em níveis normais ao longo de todo o dia, sem a necessidade de ativação de perda de calor por evaporação respiratória, que mostra uma situação de conforto térmico. Existem diferenças regionais na TS, onde as regiões do corpo que têm temperaturas mais elevadas são responsáveis pela maior parte da perda de calor sensível, como é o caso da face.

Palavras-Chave: frequência respiratória; ruminantes; temperatura retal; temperatura da superfície corporal; imagens térmicas.

\footnotetext{
* Autor para correspondência. E-mail: souza.jr@ufersa.edu.br

Recebido: 11 de dezembro de 2015.

Aceito para publicação: 15 de março de 2016.
} 


\section{INTRODUCTION}

The semi-arid region of northeastern Brazil is characterized by high temperatures and high levels of solar radiation (Silva et al., 2013; Oliveira et al., 2014; Queiroz et al., 2014) and the seasons are divided into dry and rainy. In the rainy season, solar radiation is lower than in the dry season, but the air temperature and air humidity are high. Under these conditions, the animals of zootechnical interest cannot express all of their genetic potential, where the sensible heat loss is inefficient because it requires a driving force: a gradient formed between the air temperature and the body surface.

Another important factor that interferes with the sensible heat loss is the layer of hair that acts as a heat transfer resistance from the epidermis to the environment. In cattle, only some regions of the face are not covered by hair, as the eye region. These body parts are used for dissipation of thermal energy and are called thermal windows, which have been found in birds (Tattersall et al., 2009; Souza Jr et al., 2013) and mammals (Šumbera et al., 2007; Weissenböck et al., 2010; Lima et al., 2014).

In young animals, the thermoregulatory ability has not been well defined. Some studies have been conducted to evaluate the physiological responses of calves in different types of facilities (Cunha et al., 2007a; Façanha et al., 2011; Lima et al., 2013). In addition, the analysis of thermal images of animals by infrared thermography to detect heat stress situations (Nääs et al., 2014, Torquato et al., 2015) and health status (Hoffmann et al., 2013) has grown in recent years. However, there are no studies in the literature about the application of infrared thermography and daily variation of physiological responses of crossbred calves in semiarid environment. The aim of this study was to evaluate the physiological responses of calves during rainy season in the semiarid environment.

\section{MATERIALS AND METHODS}

The study was conducted in the Dairy Cattle Production Sector of Federal Rural University of Semiarid (UFERSA), municipality of Mossoró, State of Rio Grande do Norte, Brazil $\left(05^{\circ} 11^{\prime}\right.$ South latitude, $37^{\circ} 22^{\prime}$ West longitude and $16 \mathrm{~m}$ altitude). We used 23 crossbred calves (3/4 Holstein and 1/4 Zebu of undefined breed) with predominantly black hair coat and aging between 30 and 90 days. The animals were kept in $3.00 \times 3.90 \mathrm{~m}$ pens fitted with concrete floor, guardrails $(0.90 \mathrm{~m}$ in height $)$ and ceramic tile roof $(2.50 \mathrm{~m}$ in height). The calves were fed twice a day with Tifton 85 hay $(94.64 \%$ dry matter, $7.85 \%$ mineral matter, $7.33 \%$ crude protein, $1.77 \%$ ether extract, $75.01 \%$ neutral detergent fiber, and $36.78 \%$ acid detergent fiber) and commercial feedstuff $(94.78 \%$ dry matter, $9.86 \%$ mineral matter, $18.98 \%$ crude protein, $5.62 \%$ ether extract, $36.78 \%$ neutral detergent fiber, and $6.00 \%$ acid detergent fiber). Fresh water was freely available.

Samplings were taken during eight days (twice a week in July 2011), starting at $7 \mathrm{~h}$ and ending at 18 $\mathrm{h}$. The daylight period were divided into classes, as follows: 7:00 to $9: 00 \mathrm{~h}, 10: 00$ to $12: 00 \mathrm{~h}, 13: 00$ to $15: 00 \mathrm{~h}$, and $16: 00$ to $18: 00 \mathrm{~h}$. Rectal temperature $\left(R_{\mathrm{T}},{ }^{\circ} \mathrm{C}\right)$, respiratory rate $\left(R_{\mathrm{R}}\right.$, movements per minute), body surface temperature $\left(T_{\mathrm{S}},{ }^{\circ} \mathrm{C}\right)$, air temperature $\left(T_{\mathrm{A}},{ }^{\circ} \mathrm{C}\right)$, relative humidity $\left(R_{\mathrm{H}}, \%\right)$, wind speed $\left(U, \mathrm{~m} \mathrm{~s}^{-1}\right)$ and black globe temperature $\left(T_{\mathrm{G}},{ }^{\circ} \mathrm{C}\right)$ were recorded at hourly intervals. The pluviometric precipitation recorded by the Meteorological Station of UFERSA throughout the study period was $117 \mathrm{~mm}$.

$R_{\mathrm{T}}$ was measured by a PT-100 thermoresistance connected to a portable digital thermometer (Model SALVTERM 200, Salvi, São Paulo, Brazil). $R_{\mathrm{R}}$ was determined by visual observation of the flank movements over one minute. $T_{\mathrm{A}}$ and $R_{\mathrm{H}}$ were simultaneously measured with a digital thermohygrometer (Model HT-300, Instrutherm, São Paulo, Brazil). $U$ was measured with a thermoanemometer (Model YK-2005AH, Lutron, Kolkata, India). $T_{\mathrm{G}}$ was measured with a thermocouple (Type K, Salcas, São Paulo, Brazil) that had been connected to digital thermometers (Model MT-600, Minipa, São Paulo, Brazil) and inserted into the center of a black globe $(0.15 \mathrm{~m}$ diameter hollow copper spheres placed in the center of the pen $0.5 \mathrm{~m}$ above the ground). The mean radiant temperature $\left(M_{\mathrm{RT}},{ }^{\circ} \mathrm{C}\right)$ of the environment was estimated from the meteorological variables according to the equation proposed by Silva et al. (2010).

Thermal images (Figure 1) were taken by an infrared thermal imaging camera (Model ThermaCAM b60, FLIR $^{\circledR} \quad$ Systems Inc., Massachusetts, USA; $0.01{ }^{\circ} \mathrm{C}$ resolution, 2\% accuracy) calibrated to atmospheric temperature and emissivity of biological tissues $(\varepsilon=0.98)$. Image analysis was performed using the software Flir QuickReport 1.2 (FLIR ${ }^{\circledR}$ Systems Inc.). $T_{\mathrm{S}}$ was measured in the following body regions: face, neck, body and legs. 


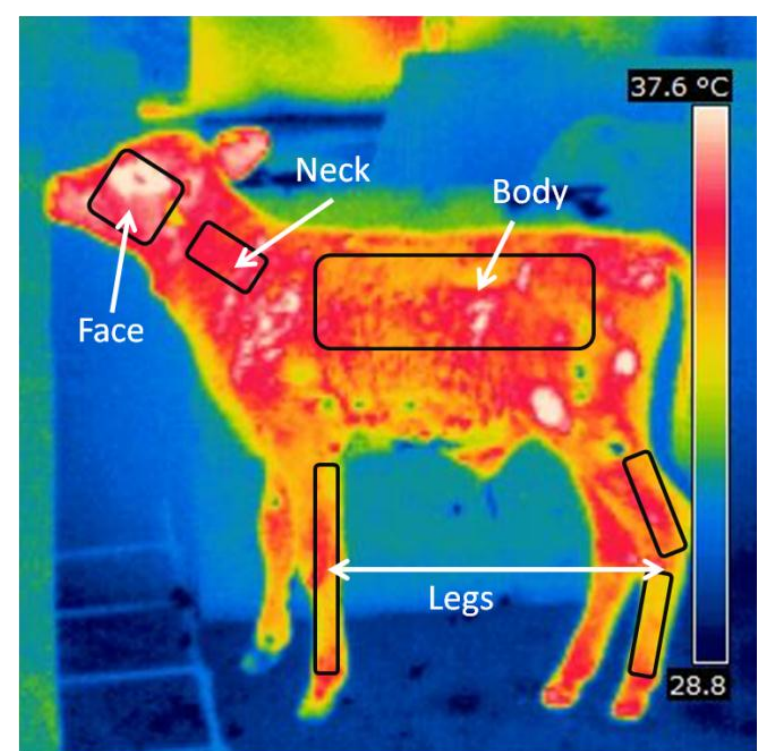

Figure 1. Thermal image of a calf obtained during the study. Body regions selected are highlighted.

Analysis of variance (ANOVA) was performed by the least-squares method using the GLM procedure in SAS software (SAS, 1999). The comparison of means was performed by the Tukey-Kramer test. The data were expressed as mean \pm standard error, and the statistical significance was set at $\mathrm{P}<0.01$. The Eq. 1 was the mathematical model used for analyzing $T_{\mathrm{R}}$ and $R_{\mathrm{R}}$ data.

$$
\text { (1) } Y_{i j}=\mu+C_{i}+\varepsilon_{i j}
$$

Where $Y_{i j}$ is the $j$ th record of the physiological variable in the $i$ th class of hour; $\mu$ is the general mean, $C$ is the fixed effect of the $i$ th class of hour ( $i$ $=1, \ldots, 4), \varepsilon_{\mathrm{ij}}$ is the residual effect, which includes others sources of variation. Eq. 2 was the mathematical model applied for $T_{\mathrm{S}}$ data.

$$
\text { (2) } \mathrm{Y}_{\mathrm{ijk}}=\mu+\mathrm{C}_{\mathrm{i}}+\mathrm{R}_{\mathrm{j}}+\varepsilon_{\mathrm{ijk}}
$$

Where $\mathrm{Y}_{\mathrm{ijk}}$ is the $k$ th observation of $T_{\mathrm{S}}$ measured in the $i$ th class of hour and $j$ th body region, $\mu$ is the general mean, $C$ is the fixed effect of the $i$ th class of hour $(i=1, \ldots, 4), R_{\mathrm{j}}$ is the fixed effect of the $j$ th body region $(j=1, \ldots, 4), \varepsilon_{\mathrm{ijk}}$ is the residual effect.

\section{RESULTS AND DISCUSSION}

Mean values of the environmental variables observed during the day are shown in Table 1. $T_{A}$ and $M_{R T}$ had their highest averages $\left(30.46^{\circ} \mathrm{C}\right.$ and $32.23^{\circ} \mathrm{C}$, respectively) in the schedule between 13:00 to $15: 00 \mathrm{~h}$. In the same time, the relative humidity had the lowest average, $57.86 \%$. On the other hand, wind speed $(U)$ did not show any increase or decrease in its values throughout the day, with the highest average $\left(0.55 \mathrm{~m} . \mathrm{s}^{-1}\right)$ being between 10:00 to $12: 00 \mathrm{~h}$.

Table 1. Means and standard errors of air temperature $\left(T_{\mathrm{A}},{ }^{\circ} \mathrm{C}\right)$, relative humidity $\left(R_{\mathrm{H}}, \%\right)$, mean radiant temperature $\left(M_{R T},{ }^{\circ} \mathrm{C}\right)$, and wind speed $\left(U, \mathrm{~m} \mathrm{~s}^{-1}\right)$ according to class of hour.

\begin{tabular}{ccccc}
\hline Meteorological variables & $T_{\mathrm{A}}\left({ }^{\circ} \mathrm{C}\right)$ & $R_{\mathrm{H}}(\%)$ & $M_{R T}\left({ }^{\circ} \mathrm{C}\right)$ & $U\left(\mathrm{~m} \mathrm{~s}^{-1}\right)$ \\
\hline Class of hour & & & & \\
Class 1 - 07:00 to 09:00 h & $26.02 \pm 0.11$ & $76.03 \pm 0.48$ & $26.82 \pm 0.14$ & $0.35 \pm 0.03$ \\
Class 2-10:00 to 12:00 h & $29.52 \pm 0.09$ & $63.17 \pm 0.53$ & $31.63 \pm 0.12$ & $0.55 \pm 0.04$ \\
Class 3 - 13:00 to 15:00 h & $30.46 \pm 0.10$ & $57.86 \pm 0.64$ & $32.23 \pm 0.10$ & $0.29 \pm 0.03$ \\
Class 4 - 16:00 to 18:00 h & $28.77 \pm 0.09$ & $65.08 \pm 0.57$ & $29.88 \pm 0.12$ & $0.04 \pm 0.01$ \\
Overall means & $28.63 \pm 0.08$ & $65.80 \pm 0.36$ & $30.08 \pm 0.10$ & $0.31 \pm 0.01$ \\
\hline
\end{tabular}

Analysis of variance (Table 2) showed that the effect of time of day was significant $(\mathrm{p}<0.01)$ for $R_{T}$ and superficial but not for $R_{R}(\mathrm{p}=0.4392)$. Also there was a significant effect of body region on the surface temperature. The least squares mean estimates of $R_{T}, R_{R}$ and $\mathrm{T}_{\mathrm{S}}$ are shown in Table 3. $T_{S}$ showed a variation similar to the variation of $T_{A}$ and $M_{R T}$, where the lowest value was found from 7:00 to 9:00 h, with an increase in the average of this variable until $13: 00$ to $15: 00 \mathrm{~h}$, decreasing in the late afternoon. The lowest mean $R_{T}$ also occurred from 7:00 to 9:00 h; however, the increase in values of this variable continued until the end of the measurements $(16: 00$ to $18: 00 \mathrm{~h})$, with an average of $38.80{ }^{\circ} \mathrm{C}$. Interestingly, the difference between the lowest and the highest mean $R_{T}$ was only 0.22 ${ }^{\circ} \mathrm{C} . R_{R}$ had an overall average of 42.48 respirations $\min ^{-1}$ and the difference between the averages throughout the day was approximately 2.0 respirations $\min ^{-1}$.

Table 2. Analysis of the variance for the effect of Time Class and body region on $T_{S}$ and Time Class on $R_{T}$ and $R_{R}$.

\begin{tabular}{lccccc}
\hline Source & Df & $T_{S}$ & df & $R_{T}$ & $R_{R}$ \\
\hline Time Class & 3 & $216.0646^{*}$ & 3 & $4.0723^{*}$ & 313.0143 \\
Body region & 3 & $458.5371^{*}$ & - & - & - \\
Error & 1314 & 1,6152 & 266 & 0.1769 & 216.3693 \\
\hline
\end{tabular}

$* \mathrm{P}<0.01$ 
The semi-arid region of Brazil is characterized by high temperature and solar radiation levels throughout the year, which is an obstacle to the cattle industry. These environmental factors directly affect the thermoregulation of animals (Silva et al., 2013), and the provision of a favorable environment becomes essential, especially for calves. Young animals are particularly vulnerable and the continuous exposure to a hot environment raises the rectal temperature and respiratory rate, while decreases feed intake, resulting in less body development.

The respiratory rate is the first to be affected by rising air temperature. It is the physiological variable most affected in animals in a tropical environment. The main advantage of using respiratory rate as a method of determining the conditions of thermal stress is the ease of measurement, without the need for additional equipment (Brown-Brandl et al., 2005).

On the other hand, body temperature is a physiological indicator used as the final response to the tension received from the environment, that is, when mechanisms of thermal dissipation, particularly transfer of latent heat, are no longer sufficient to thermal equilibrium between animals and environment (Scharf et al., 2008). Kendall (1947) and Beakley and Findlay (1953) had already discussed the importance of changes in rectal temperature in the middle of the twentieth century. They suggested that measurement of the normal range of diurnal fluctuations could be a valuable indication of the ability of bovine calf support on thermal stress.

Cunha et al. (2007a, 2007b), studying crossbred Holstein $\times$ Zebu calves, noted that the respiratory rate and rectal temperature of the animals showed higher average values in the afternoon. These results agree with the rectal temperature readings in the present study, because this time the environment was characterized by high temperatures (Table 1), where the animals received the greatest amount of heat. Even with the rise in rectal temperature in the afternoon, the values are within the limits of variation established by Dukes (1996) for dairy calves $\left(38.0-39.3{ }^{\circ} \mathrm{C}\right)$.

Façanha et al. (2011) also found that Holstein calves in temperate climates had a higher respiratory rate at $15: 00 \mathrm{~h}$. compared to measurements made at 7:00 h. Similar results were found by Lima et al. (2013) studying crossbred calves in equatorial environment. However, in the current study, the respiratory rate did not show a significant change at different times of the day (Table 2). Despite the increase in rectal temperature (in 13:00 to $15: 00 \mathrm{~h}$ ), the calves did not use the respiratory rate as a way to lose the excess heat absorbed from the environment, which was different from the results found by the above authors. Probably the sweating rate of the studied calves has been raised. The sweating rate in dairy cows in semi-arid environment corresponds to $72.7 \%$ of the total evaporative heat loss (Silva et al., 2012).

Another interesting result of this study was the continuous increase in rectal temperature from 16:00 to $18: 00 \mathrm{~h}$, even with a decrease in the values of environmental variables. It was verified that calves stocked body heat to dissipate it during the night, when the air temperature is low, by facilitating the loss of sensible heat. Finch (1985) and McLean et al. (1983) have reported this mechanism, where a high-temperature condition of thermal equilibrium cannot be reached and, in this case, the animal begins to store energy in tissues, resulting in increased body temperature and no activation of the mechanisms of non-evaporative heat loss.

The body surface temperature of animals directly influences the sensible heat loss. In high temperatures, this mechanism can become a way of heat gain (Maia et al., 2005; Souza Jr et al., 2013). In these conditions, the thermal equilibrium can be affected, causing direct changes to the internal temperature and heat loss by evaporation.

The coat surface temperature directly depends on the ambient conditions, that is, abrupt changes in the environment variables result in changes in the coat temperature. As a precise way to measure this variable, infrared thermography has been used in studies of thermal physiology since the 1960 for not being an invasive method (McCafferty, 2007). These results are in accordance with the present study, where at times of higher $T_{A}$ and $M_{R T}$, the highest averages of surface temperature were found, resulting, in these same times, in higher body temperature caused by excess heat from the environment.

Regarding the regional distribution of the $T_{A}$, the highest average was found on the face, which differed statistically from other body regions (Table 3). The neck differed significantly from the temperature found on the body and legs, which did not differ between them. The body regions which do not coat (hair or feathers) exhibit higher temperatures because they are fully exposed to the environment and serve as sites of thermolysis. In the present study, the facial area had the highest temperature, mainly because it is a highly vascularized, agreeing with the results of Martello et al. (2016) and Hoffmann et al. (2015) with steers and calves, respectively. 
Table 3. The least squares means of rectal temperature $\left(R_{T},{ }^{\circ} \mathrm{C}\right)$, respiratory rate $\left(R_{R}\right.$, resp $\left.\min ^{-1}\right)$ and surface temperature $\left(T_{S},{ }^{\circ} \mathrm{C}\right)$.

\begin{tabular}{lccccc}
\hline Mean & $\mathrm{n}$ & $T_{S}$ & $\mathrm{n}$ & $R_{T}$ & $R_{R}$ \\
\hline Overall & 1321 & $32.60 \pm 0.05$ & 286 & $38.68 \pm 0.01$ & $42.48 \pm 0.61$ \\
Time Class & & & & & \\
7:00 to 9:00 h & 359 & $32.04 \pm 0.07^{\mathrm{c}}$ & 71 & $38.58 \pm 0.02^{\mathrm{b}}$ & $43.61 \pm 0.77$ \\
10:00 to 12:00 h & 349 & $33.39 \pm 0.07^{\mathrm{b}}$ & 72 & $38.59 \pm 0.02^{\mathrm{b}}$ & $42.07 \pm 0.77$ \\
13:00 to 15:00 h & 313 & $33.92 \pm 0.07^{\mathrm{a}}$ & 72 & $38.74 \pm 0.02^{\mathrm{a}}$ & $41.33 \pm 0.83$ \\
16:00 to 18:00 h & 300 & $33.23 \pm 0.07^{\mathrm{b}}$ & 71 & $38.80 \pm 0.02^{\mathrm{a}}$ & $42.62 \pm 0.83$ \\
Body region & & & & - \\
Face & 322 & $35.45 \pm 0.08^{\mathrm{a}}$ & - & - & - \\
Legs & 326 & $32.35 \pm 0.08^{\mathrm{c}}$ & - & - & - \\
Body & 334 & $32.49 \pm 0.08^{\mathrm{c}}$ & - & - & - \\
Neck & 334 & $33.09 \pm 0.08^{\mathrm{b}}$ & - & - & - \\
\hline P & & & & - \\
\hline
\end{tabular}

$\mathrm{P}<0.01 ; \mathrm{n}=$ number of observations. Means with the same superscript, for each effect, do not differ statistically by Tukey's test.

The lowest average was found in the legs (32.35 $\left.{ }^{\circ} \mathrm{C}\right)$. Our results corroborate Montanholi et al. (2008), where the temperature of the legs was lower than that of the body, about $8.0{ }^{\circ} \mathrm{C}$ in dairy cows. Kotrba et al. (2007) also found low values for the foreleg of dairy cows. The temperature of the extremities of the body such as the legs are dependent on blood flow control, which is mediated by the hypothalamus and influenced by external temperature changes. In this study, due to the fact that the temperature was not high, peripheral vasodilation in the legs was not triggered.

Regarding the neck, the average temperature (33.09 $\left.{ }^{\circ} \mathrm{C}\right)$ was higher than and differed from that found in the body $\left(32.49{ }^{\circ} \mathrm{C}\right)$. Knizkova et al. (1996) also found high temperatures in dairy cows and Silva et al. (2013) in goats without defined breed, but no difference between this region and the body.

\section{CONCLUSION}

In the rainy season of the equatorial semi-arid region of Brazil, the calves maintained their body temperature at normal levels throughout all day without the activation of heat loss by respiratory evaporation, which shows a situation of thermal comfort. There are regional differences in the surface temperature of calves in semi-arid equatorial environment, where the body regions that have higher temperatures are responsible for most of the high sensible heat loss, in the case, the face.

\section{REFERENCES}

Beakley, W. R.; Findlay, J. D. The effect of environmental temperature and humidity on the rectal temperature of calves. Journal of Agricultural Science, v.45, p.339-352, 1953.

Brown-Brandl, T. M.; Eigenberg, R. A.; Nienaber, J. A.; Hahn, G. L. Dynamic response indicators of heat stress in shaded and non-shaded feedlot cattle, Part 1: analyses of indicators. Biosystems Engineering, v.90, p.451-462, 2005.
Cunha, D. N. F. V.; Campos, O. F.; Pereira, J. C.; Pires, M. F. A.; Lizieire, R. S.; Martuscello, J. A. Desempenho, variáveis fisiológicas e comportamento de bezerros mantidos em diferentes instalações: época chuvosa. Brazilian Journal of Animal Science, v.36, p.1140-1146, 2007a.

Cunha, D. N. F. V.; Campos, O. F.; Pereira, J. C.; Pires, M. F. A.; Oliveira, R. F. M.; Martuscello, J. A. Desempenho, variáveis fisiológicas e comportamento de bezerros mantidos em diferentes instalações: época seca. Brazilian Journal of Animal Science, v.36, p.847-854, 2007 b.

Dukes, H. H. Fisiologia dos animais domésticos. 7. ed. Rio de Janeiro: Guanabara Koogan, 1996.

Façanha, D. A. E.; Vasconcelos, A. M.; Silva, W. S. T.; Chaves, D. F.; Morais, J. H. G.; Olivo, C. J. Respostas comportamentais e fisiológicas de bezerros leiteiros criados em diferentes tipos de instalações e dietas líquidas. Acta Veterinaria Brasilica, v.5, p.250-257, 2011.

Finch, V. A. Comparison of non-evaporative heat transfer in different cattle breeds. Australian Journal of Agricultural Research, v.36, p.497-508, 1985

Hoffmann, G.; Schmidt, M.; Ammon, C.; Rose-Meierhöfer, S.; Burfeind, O.; Heuwieser, W.; Berg, W. Monitoring the body temperature of cows and calves using video recordings from an infrared thermography camera. Veterinary Research Communications, v.37, p.91-99, 2013.

Hoffmann, G.; Schmidt, M.; Ammon, C. First investigations to refine video-based IR thermography as a non-invasive tool to monitor the body temperature of calves. Animal, v.20, p.1-5, 2015 .

Kendall, S. B. Relationship between breed of cattle and ability to maintain a constant body temperature under tropical conditions. British Veterinary Journal, v.104, p.112-115, 1947.

Knizkova, I. Evaluation of evaporative cooling on the changes of cattle surface body temperatures with use of thermovision. Živočisna Výroba, v.41, p.433-439, 1996.

Kotrba, R.; Knizkova, I.; Kunc, P.; Bartos, L. Comparison between the coat temperature of the eland and dairy cattle by infrared thermography. Journal of Thermal Biology, v.32, p.355-359, 2007.

Lima, P. O.; Souza Jr, J. B. F.; Lima, R. N.; Oliveira, F. C. S.; Domingos, H. G. T.; Tholon, P.; Miranda, M. V. F. G. Effect of time of day and type of shading on the physiological responses of crossbred calves in tropical environment. Journal of Animal Behaviour and Biometeorology, v.1, p.7-12, 2013. 
Lima, L. R.; Souza Jr, J. B. F.; Ricarte, A. R. F.; Santos, E. A. A.; Costa, L. L. M.; Oliveira, M. F.; Barbosa Filho, J. A. D. Aplicação da termografia infravermelha para determinar os padrões de temperatura da bolsa escrotal de catetos (Tayassu tajacu Linnaeus, 1758). Journal of Animal Behaviour and Biometeology, v.2, p.85-89, 2014.

Maia, A. S. C.; Da Silva, R. G.; Batiston Loureiro, C. M. Sensible and latent heat loss from the body surface of Holstein cows in a tropical environment. International Journal of Biometeorology, v.50, p.17-22, 2005.

Martello, L. S.; Silva, S. L.; Gomes, R. C.; Corte, R. R. P. S.; Leme, P. R. Infrared thermography as a tool to evaluate body surface temperature and its relationship with feed efficiency in Bos indicus cattle in tropical conditions. International Journal of Biometeorology, v.60, p.173-181, 2016.

McCafferty, D. J. The value of infrared thermography for research on mammals: previous applications and future directions. Mammal Review, v.37, p.207-223, 2007.

McLean, J. A.; Stombaugh, D. P.; Downie, A. J.; Glasbey, C. A. Body heat storage in steers (Bos taurus) in fluating thermal environments. Journal of Agricultural Research, v.100, p.315322, 1983.

Montanholi, Y. R.; Odongo, N. E.; Swanson, K. C.; Schenkel, F. S.; McBride, B. W.; Miller, S. P. Application of infrared thermography as an indicator of heat and methane production and its use in the study of skin temperature in response to physiological events in dairy cattle (Bos taurus). Journal of Thermal Biology, v.33, p.468-475, 2008.

Nääs, I. A.; Garcia, R. G.; Caldara, F. R. Infrared thermal image for assessing animal health and welfare. Journal of Animal Behaviour and Biometeorology, v.2, p.66-72, 2014.

Oliveira, S. E. O.; Costa, C. C. M.; Souza Jr, J. B. F.; Queiroz, J. P. A. F.; Maia, A. S. C.; Costa, L. L. M. Short-wave solar radiation level willingly tolerated by lactating Holstein cows in an equatorial semi-arid environment. Tropical Animal Health and Production, v.46, p.1413-1417, 2014.

Queiroz, J. P. A. F.; Souza Jr, J. B. F.; Lima, H. F.; Costa, M. K. O.; Macedo Costa, L. L.; Arruda, A. M. Daily variations in the thermoregulatory behaviors of naked neck broilers in an equatorial semi-arid environment. International Journal of Biometeorology, v.58, p.1259-1264, 2014.

SAS Institute Inc. SAS/STAT User's guide, Version 8. Cary: SAS Institute, Inc., 1999. p.295.

Scharf, B.; Wax, L. E.; Aiken, G. E.; Spiers, D. E. Regional differences in sweat rate response of steers to short-term heat stress. International Journal of Biometeorology, v.52, p.725732, 2008.

Silva, R. G.; Guilhermino, M. M.; Morais, D. A. E. F. Thermal radiation absorbed by dairy cows in pasture. International Journal of Biometeorology, v.54, p.5-11, 2010.

Silva, R. G.; Maia, A. S. C.; Costa, L. L. M.; Queiroz, J. P. A. F. (2012) Latent heat loss of dairy cows in an equatorial semi-arid environment. International Journal of Biometeorology, v.56, p.927-932, 2012.

Silva, J. J. F. C.; Torquato, J. L.; Sá Filho, G. F.; Souza Jr, J. B. F.; Macedo Costa, L. L. Evaporação cutânea e respostas fisiológicas de caprinos Canindé em ambiente equatorial semiárido. Journal of Animal Behaviour and Biometeorology, v.1, p.13-16, 2013.

Souza Jr, J. B. F.; Queiroz, J. P. A. F.; Domingos, H. G. T.; Torquato, J. L.; Sá Filho, G. F.; Macedo Costa, L. L. Avaliação termográfica de codornas japonesas (Coturnix coturnix japonica). Journal of Animal Behaviour and Biometeorology, v.1, p.61-64, 2013.

Šumbera, R.; Zelová, J.; Kunc, P.; Knízkova, I.; Burda, H. Patterns of surface temperatures in two mole-rats (Bathyergidae) with different social systems as revealed by IR-thermography. Physiology \& Behavior, v.92, p.526-532, 2007.

Tattersall, G. J.; Andrade, D. V.; Abe, A. S. Heat exchange from the toucanbill reveals a controllable vascular thermal radiator. Science, v.325, p.468-470, 2009.

Torquato, J. L.; Souza Jr, J. B. F.; Queiroz, J. P. A. F.; Costa, L. L. M. Termografia infravermelha aplicada a emas (Rhea americana). Journal of Animal Behaviour and Biometeorology, v.3, p.51-56, 2015.

Weissenböck, N. M.; Weiss, C. M.; Schwammer, H. M.; Kratochvil, H. Thermal windows on the body surface of African elephants (Loxodonta africana) studied by infrared thermography. Journal of Thermal Biology, v.35, p.182-188, 2010 . 